This is a self-archived version of an original article. This version may differ from the original in pagination and typographic details.

Author(s): Anttila, Timo; Oinas, Tomi

Title: Patterns of Working Time and Work Hour Fit in Europe

Year: 2018

Version: Accepted version (Final draft)

Copyright: (c) The Author(s) 2018.

Rights: In Copyright

Rights url: http://rightsstatements.org/page//nC/1.0/?language=en

Please cite the original version:

Anttila, T., \& Oinas, T. (2018). Patterns of Working Time and Work Hour Fit in Europe. In M. Tammelin (Ed.), Family, Work and Well-Being : Emergence of New Issues (pp. 49-61). Springer International Publishing. SpringerBriefs in Well-Being and Quality of Life Research.

https://doi.org/10.1007/978-3-319-76463-4_5 


\section{Patterns of working time and work hour fit in Europe}

Author: Timo Anttila, Tomi Oinas

The requirements for more flexible forms of production are common in all advanced economies. At the same time, the flexibilisation of working times and workplaces has become an increasing focus for analysis when addressing work-life balance. This chapter approaches flexibilisation as a transition from an industrial working time regime to a postindustrial working time regime. This chapter provides an introduction to the latest comparative research on working time flexibility and the work-life balance in Europe. The chapter also discusses the flexibility of working times and places from both employers' and employees' perspectives. By using the latest European Working Condition Survey (2015) this chapter examines how working times and work-life balance are associated in different welfare regimes.

\section{The flexibilisation of working times}

Working time has been at the heart of the political agenda and is a central question for the organization of everyday life (Adam 1995; Fagan \& Lallement 2000; Epstein \& Kalleberg 2001). Paid work has a major impact on living conditions, use of time and social networks. The allocation of time is also a central issue in (European) social policy: one of the main aims of the European Social Policy Agenda has been to increase the employment rate, especially among women. This goal is expected to be reached with a good balance between paid work and other life spheres.

Since the 1970s the conditions of work have changed and eroded both the traditional full-time worker and the standard employment relationship (Supiot 2001, 62-64). The industrial working time regime is been replaced with the post-industrial working time regime. The core features of the industrial working time regime means an approximately eight-hour working day (duration) with daytime work and free weekends (timing) being the normal working time. The standard employment relationship is also linked with stable, continuous, full-time work and with a normal life-course (Supiot 2001), following a male employment pattern and male work history. 
Along with the standardisation of working time in advanced societies, and especially the expansion of the welfare state, gender- and age-based norms for participation in work life were also standardised. Both the education system and the concept of retirement established a division between youth, economic activity and retirement (Fagan \& Lallement 2000). At the same time, participation in full-time wage work was conforming to a certain societal time structure that has been a part of the moral and economic foundation of the welfare state.

The new, post-industrial working time regime is characterised by the deregulation of collective norms, diversification of the length and pattern of working time, blurring of the limits of working time and the erosion of normal biographies (Brannen 2005; Perrons et al. 2005; Craig and Powell 2011; Fagan et al. 2012). There does not seem to be a consensus on the extent of the change in working time practices nor on the implications of the change (Rubery et al. 2005). The extent and consequences of the post-industrial working time regime vary across socioeconomic groups (Warren 2003). On the one hand, among employees in dynamic sectors and in a good labour market position, change seems to signify a lengthening and intensification of working time, the marginalisation of private life and concentration on work (Hochschild 1997). On the other hand, the poorly educated and those belonging to the lower occupational groups are more affected by work during unsocial hours, which may have negative impacts on individual and family well-being (Warren 2003).

Thus, working times and time structures are, to a great extent, socially constructed and gendered. During the last decades, however, the 'male-breadwinner' arrangement has been eroded and the 'dual-earner' household has become a more common arrangement in industrial countries (Gallie \& Russell 2009).

There seems to be no consensus on the reasons that explain why normal working time has been eroded. However, it seems clear that the extension of the service economy has challenged industrial work and industrial working time practices (Perrons et al. 2005). Alain Supiot (2001) discusses change as part of the flexibilisation of product markets, which departs from the Taylorian mass-production principles and adopts the 'just-in-time' production model. 
Normal working time and normal forms of employment have allowed for the long-term planning of the use of labour and are thus especially suitable for large-scale mass production. The historical precondition has been stable production and demand. The fluctuations in demand have been buffered by the stocks of mass production or paid for with more expensive overtime or the under-exploitation of labour. The labour force has been relatively homogenous in quality and in its interests. The symbiosis of the form of normal working time and form of employment has been included in the Fordist paradigm of production.

Contemporary sociological analyses of work emphasise that the processes of working life are leading to a situation in which the importance of collective regulation and uniform time structures is lessening. Continuing the chain of paradigmatic changes in industrial production, the normalisation of non-standard working hours has been seen as an aspect of the transition from a Fordist to a post-Fordist era. The historical trend for the reduction and normalisation of working hours stopped in the 1970s, and the paradigm gradually changed into a flexible production paradigm (Bosch 1999; Beck 2000, 67-72).

The new service-dominated economy adopts similar flexible forms of labour use. Business theory has introduced an 'uno actu principle' which describes the important difference between services and other production. Services are produced and consumed in one act. Services cannot be stored like products. Accordingly, the staffing of service production must follow the customer flow, resulting in the flexible use of working time. In addition, the evolving post-industrial working time regime is linked to the 'new economy', characterised by globalization, 24-hour financial markets, informationalisation and networking across time zones.

\section{Institutional anchors}

The requirements for more flexible forms of production that are able to adapt to demand cycles are common in all advanced economies. Flexibility has been a key concept in the political working-life debates for a long time. However, the implementation of the flexibilisation of work (times) has varied between countries. Despite institutional convergence in Europe, working time arrangements are highly dependent on the cultural, institutional and regulatory environments of the society (Anxo \& O'Reilly 2000; Eurofound 2017). European companies are subject to institutional regulations which vary from one 
country to another. They are also confronted with varying demands from employees. In addition, cross-national variation in production systems has led to quite different employer strategies for achieving a competitive advantage in the markets. Expanding comparative research literature has tried to sketch European countries' production regimes, industrial relations and countries' welfare state institutions and look at how these institutional conditions mediate globalisation's effects (Gallie \& Russell 2009; Gornick \& Heron 2006). For example, national industrial relation systems define to what extent working time conditions are regulated by industry-wide collective bargaining or by enterprise-level negotiations (Rubery, Smith \& Fagan 1998).

\section{The dimensions of working time: Individual costs and benefits?}

We can conceptualise the changing relations of work, time and place as a transition from the industrial working time regime to the post-industrial working time regime. Working time regime here refers to both the legal contracts regulating working time and to working time practices. These practices can be conceptualized with four dimensions. These are, firstly, the number of hours worked (duration); secondly, when individuals work (timing); thirdly, the work-time intensity (tempo); and fourthly, the degree of time autonomy the individuals have over their working hours (time autonomy / schedule autonomy) (Adam 1995; Noon \& Blyton 1997; Fagan 2001). All these dimensions of working time have been changing with the emerging post-industrial working time.

\section{The duration of working time}

The length of working time remains, however, a topic of intense political debate (Messenger 2011). Overall, the concept of working hours has become more obscure; studies have reported diverse results, for example, regarding the frequency of long working hours. Long working hours are associated with adverse direct and indirect outcomes for employees physically, psychologically and socially (Joyce et al. 2010). In addition, long working hours can lead to unhealthy behaviour patterns and general exhaustion (Kodz et al. 2003; Steptoe et al. 1998;). Long working hours are also increasingly discussed in the literature with regard to their impact on personal relationships and home life (Moen et al. 2008; Bianchi \& Milkie, 
2010) with contradictory findings. A number of studies have shown that long working hours are often done reluctantly, and employees perceive detrimental effects on their leisure time and personal relationships (Hochschild 1997; Gray et al. 2004), including lower marital quality and having less time with children (Bianchi \& Milkie 2010; Warren 2010; Chatzitheochari \& Arber 2012). However, many workers who work long hours may do so because they regard this desirable (Southerton \& Tomlinson 2005). Long working hours can enhance career advancement, contribute to one's economic welfare and reduce job insecurity.

Also short hours are problematic for employees because of low pay, and a lack of goodquality jobs. Very short part-time work often associates with other harmful work conditions, such as a lack of career possibilities and protection, and low possibilities for workplace training.

The timing of work hours

Regardless of the popular message that western societies are moving towards the 24-hour economy, which means more people working outside daytime hours and weekdays, the European Working Conditions Surveys (EWCSs) do not give much support for this claim (Parent-Thirion et al. 2007, 20). Still, a large proportion of employees work during nonstandard hours. While non-standard work schedules have traditionally been concentrated on the manufacturing sector, the diffusion of opening hours in the service sector has increased the demand for non-standard work hours (Craig \& Powell 2011; Liu et al. 2011; Strazdins et al. 2004).

Non-standard work times are often beneficial from the viewpoint of company economy but potentially inconvenient from the viewpoint of employees, who miss out on family and social life (Golden 2015) and may suffer adverse health outcomes (Presser 2003; Strazdins et al. 2011). Studies have, however, showed mixed effects. Some studies have identified that parental time with children increases with non-standard hours (Täht 2011) and that it can also enable meeting family responsibilities, for example allowing 'spilt-shift' parenting (Strazdins et al. 2004; Liu et al. 2011). It is likely that the mixed findings are due to differences in measures and country differences (Täht 2011), such as social policy, that may or may not support working parents. 
Some of the most persuasive evidence for the changing time regime is the lively discussion concerning the increased experiences of time pressure and time "famine", which can be considered as new social problems in post-industrial societies (Garhammer 2002; Rosa 2003). Time is popularly identified with famine, a "squeeze" and accelerated use (Hochschild 1997; Florida 2002). Perceived time pressure at work has increased in most European countries during recent decades (Burchell et al. 2009; Eurofound 2012). New forms of work organisation - such as high-performance and high-involvement management practices, which include incentives combining effort with pay - have been linked to the intensification of work (Green 2004).

Time pressure may be harmful to employees' health and well-being. Psychosocial time pressures - such as tight deadlines, perceived time pressure or a time famine - may be more important for health than the hours spent on the job (Moen, Kelly \& Lam 2013). Time pressure can be expected to increase employees' negative emotions, stress and fatigue. These reactions may spill over into family life, which may increase work-to-family conflict by limiting employees' abilities to perform family duties (Voydanoff 2004).

\section{Working time autonomy}

Individual working time control is defined as the possibility to meet the needs of employees, providing them with autonomy regarding the start and end times of their shifts, breaks, days off, holidays and the total number of work hours (Beckers et al. 2012). Hill et al. (2008) defined a similar concept - workplace flexibility - as the ability of workers to make choices influencing when, where and for how long they engage in work-related tasks. As autonomy enables the adjustment of working time to meet obligations, needs and activities in private life, it is expected to advance a better work-non-work balance (Fagan et al. 2012). It is commonly presented that autonomy has the potential to act as a buffer against the negative effects of long, pressured or unsocial working hours (Moen et al. 2008). Any health consequences are likely to be lower if an individual can choose whether or not to work a particular shift or extra hours (Moen et al. 2008). Earlier research has presented two separate mechanisms that potentially explain the favourable association of working time autonomy with well-being. Firstly, control over working time helps people align their work 
commitments with their private life. Secondly, autonomy can prevent work overload and sustain an effort-recovery balance (Nijp et al. 2012).

\section{Working time flexibility and work-life balance}

Working time flexibility is in a complex relationship with work-life balance (Eurofound 2017b). Flexible does not necessarily equate with being family-friendly. Firstly, it should be asked: Flexibility for whom? (Karlsson 2007; Chung and Tijdens 2013). Some flexible work arrangements are driven primarily by employers' interests and targets to optimize the use of both human labour and other means of production. Other arrangements may be launched through employees' interest in enhancing the balance between work and other life spheres (Fleetwood 2007). In practice, it is difficult to define exactly it is difficult to be sure which category to place an arrangement. Unsocial work hours (e.g. evening and night work) are commonly used to make the most of capital investments (in the process industry) or to meet the various times of customer demand (in the service sector). Typically, high work-time autonomy is expected to represent employee-friendly flexibility (Chung and Tijdens 2013). Furthermore, flexible work practices, such as remote working and individually defined work hours, which are commonly considered as arrangements that facilitate a better work-life balance.

Anttilas and colleagues' (2015) research focused on flexible working hours and work-life balance in Europe. They emphasized that the flexibility of working time and place includes many dimensions and that the comparison of different dimensions of working time is necessary as the dimensions have different impacts on work-life balance. The study separated the time-related dimensions of flexibility: the number of hours worked (duration), when the hours are worked (timing), the degree of time autonomy the individuals have over 
their working hours (time autonomy) and work-time intensity (tempo). In addition to timerelated dimensions, the study also analysed a place-related dimension (multiple work locations) that exemplified the flexibilisation of workspaces. The results indicated that the flexibility of working time predicts the perceived work-life balance and that the timing (unsocial hours) and duration of work were important determinants of work-life balance. In contrast, spatial flexibility was not associated with the perceptions of work-life balance.

Other earlier studies on the linkages between working time dimensions show that a long working week (Grzywacz \& Marks 2000; Crompton \& Lyonette 2006), unsocial working hours (Gallie \& Russell 2009) and a high working-time tempo (Grzywacz \& Marks 2000; McGinnity \& Calvert 2009) usually have negative effects, and working time autonomy has positive effects on employees' perceptions of the balance between work and other life spheres (Fagan et al. 2012).

\section{How working times are associated with work-life balance in Europe}

In the next chapters we describe the connections of work-time dimensions to perceived work-life balance. In the latest EWCS, conducted in 2015 by the European Foundation for the Improvement of Living and Working Conditions (Eurofound), work-life balance was assessed by linking one's home and other commitments straight to working times: "How well do your working hours fit in with family or social commitments outside work?" The response scale was from 1 ('not at all well') to 4 ('very well'). In picture 1 the answers are presented according to the regime typology of countries. This country clustering comes close to a classification of welfare state capitalism (Esping-Andersen 1990). 
The Scandinavian country cluster represents a relatively homogeneous group of countries with generous and inclusive welfare state systems. Southern countries are characterised by relatively limited social protection systems and a traditional gender division of labour. Ireland and the UK represent the ideal type of regime oriented to a liberal market with relatively lowlevel regulation and a residual welfare state system. The eastern cluster includes countries which are less homogeneous post-communist economies with relatively high female employment and full-time rates, and a relatively high share of dual-earner households. The continental cluster consists of the same countries as those in the welfare state classification (Esping-Andersen 1990).

The results show that most European workers perceive their working hours to fit well with their home and personal life commitments. The respondents from the Scandinavian cluster and liberal cluster countries (Ireland and the UK) are more positive about their work-hour fit. In these clusters more than one third of the respondents were fully satisfied with their working times. In contrast, the proportion of those fully satisfied was clearly lower in the southern $(20 \%)$ and eastern $(25 \%)$ clusters. 


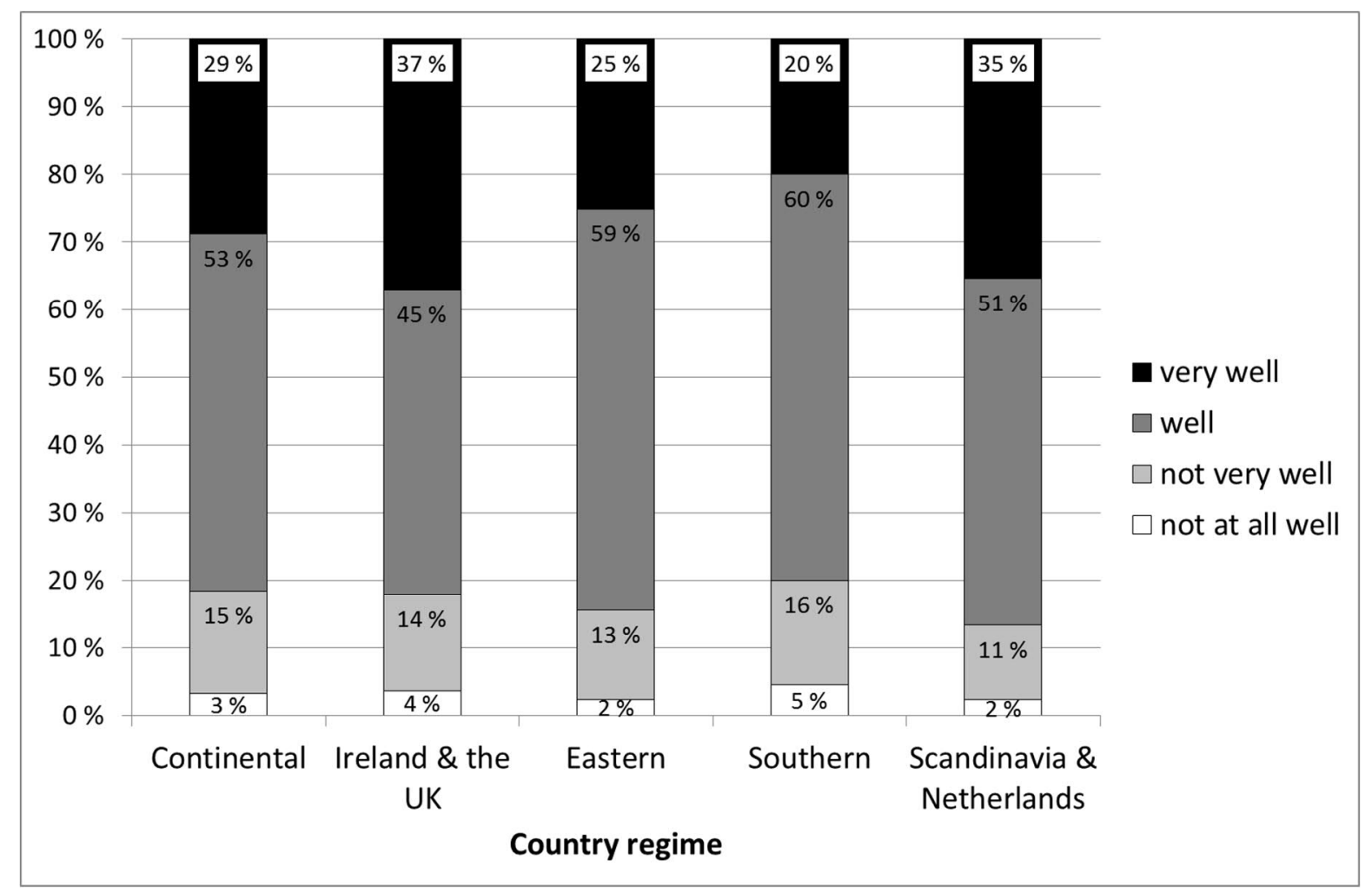

Figure 1. Work hour fit with family or social commitments outside work in five country regimes ${ }^{1}$

Taking into account the variation of the perceived work-life balance in country clusters, it is interesting to look closer into how the prevalence of working time dimensions vary between these clusters. Figure 2 shows that the Scandinavian cluster in particular differs substantially from the others. The Scandinavian cluster is characterized by high working time autonomy and workplace flexibility. Weekly working hours are relatively low and unsocial hours are not common. The level of time pressure is slightly above the average. The continental country cluster has a similar profile, but the levels of autonomy and workplace flexibility are lower. The southern and eastern country clusters represent a working time pattern which is characterized by low autonomy and low workplace flexibility. In the eastern cluster the

\footnotetext{
${ }^{1}$ Continental: Austria, Belgium, France, Germany, Luxemburg

Eastern: Bulgaria, Croatia, Czech Republic, Estonia, Hungary, Latvia, Lithuania, Poland, Romania, Slovakia, Slovenia

Southern: Cyprus, Greece, Italy, Malta, Portugal, Spain

Scandinavia and Netherlands: Denmark, Finland, Netherlands, Norway, Sweden
} 
length of working time is higher than in the other clusters but, at the same time, perceived time pressures at work are at a lower level. The liberal Ireland and UK cluster showed a high work-hour fit, and interestingly it is achieved with a relatively high level of unsocial hours and time pressures. Also, working time autonomy and workplace flexibility are above the average level.

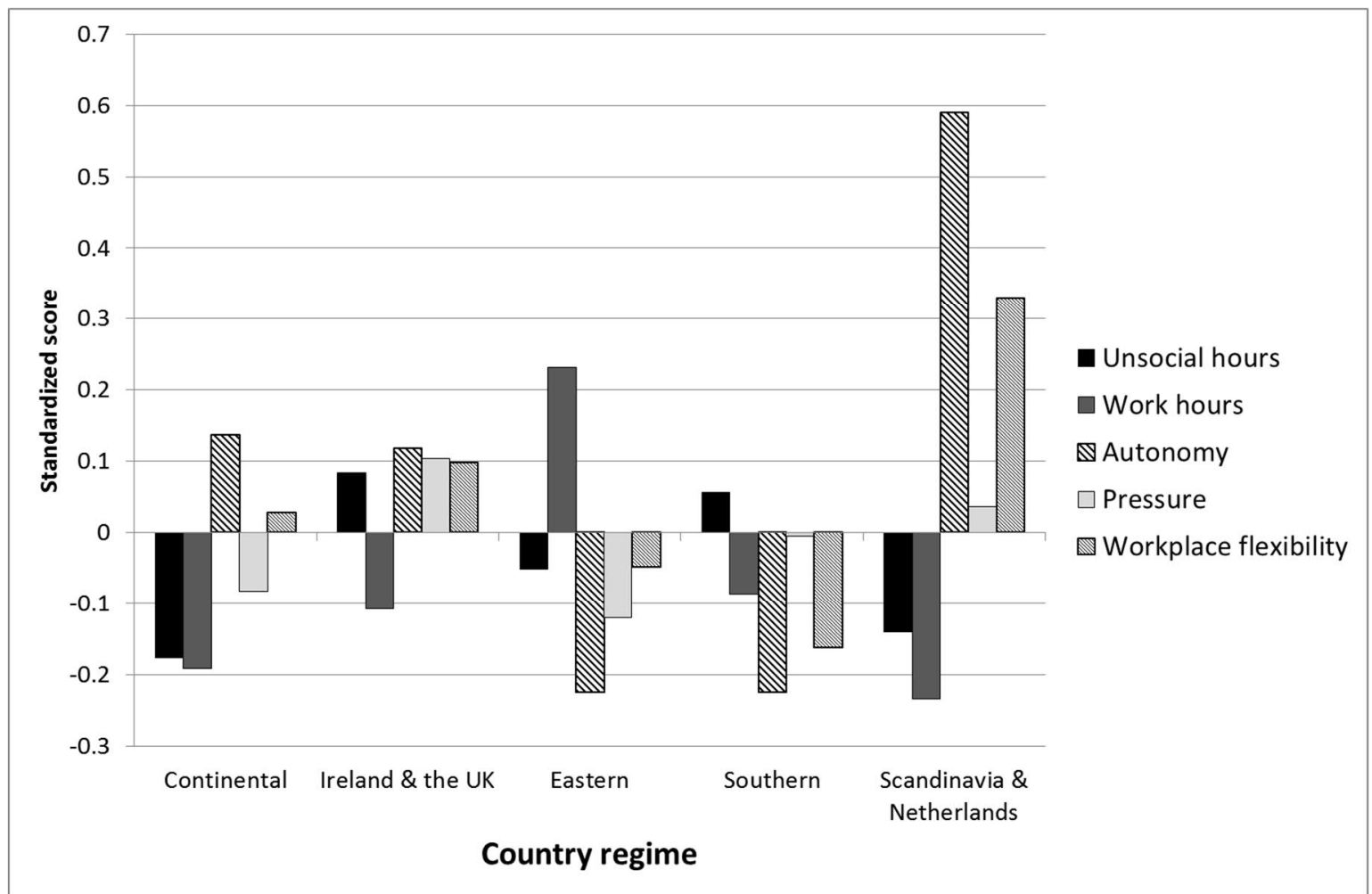

Figure 2. Dimensions of working time by country regime ${ }^{2}$

\section{How are working time dimensions associated with work-life balance?}

Working time dimensions are expected to have their specific effect on work-life balance. Also the strength of the effect may vary. In order to estimate the effect size of each working time dimension, a regression model is estimated. Figure 3 show the results of the regression

\footnotetext{
${ }^{2}$ Continental: Austria, Belgium, France, Germany, Luxemburg

Eastern: Bulgaria, Croatia, Czech Republic, Estonia, Hungary, Latvia, Lithuania, Poland, Romania, Slovakia, Slovenia

Southern: Cyprus, Greece, Italy, Malta, Portugal, Spain

Scandinavia and Netherlands: Denmark, Finland, Netherlands, Norway, Sweden
} 
model which explains to what extent each dimension affects (negatively or positively) the perceived work-life balance. The red bars illustrate a negative effect and bar length illustrates effect size. In this sample, covering all European respondents, unsocial hours are the most detrimental to the work-life balance. In addition, time pressures and long working hours reduce the balance. Also workplace flexibility, practically describing multi-locational work, has a negative effect. It has been argued that spatial flexibility and the opportunity to work at home is central to the work-life balance and that telework or home-based work has the potential to enhance the work-life balance. However, multi-located work may also be disturbing and the entry of work into private spheres may negatively affect family relationships among partners and children due to simultaneous demands to follow both work and home roles. Working time autonomy is, as expected, a working time dimension that $\begin{array}{llll}\text { enhances the balance. } & \text { work-life }\end{array}$

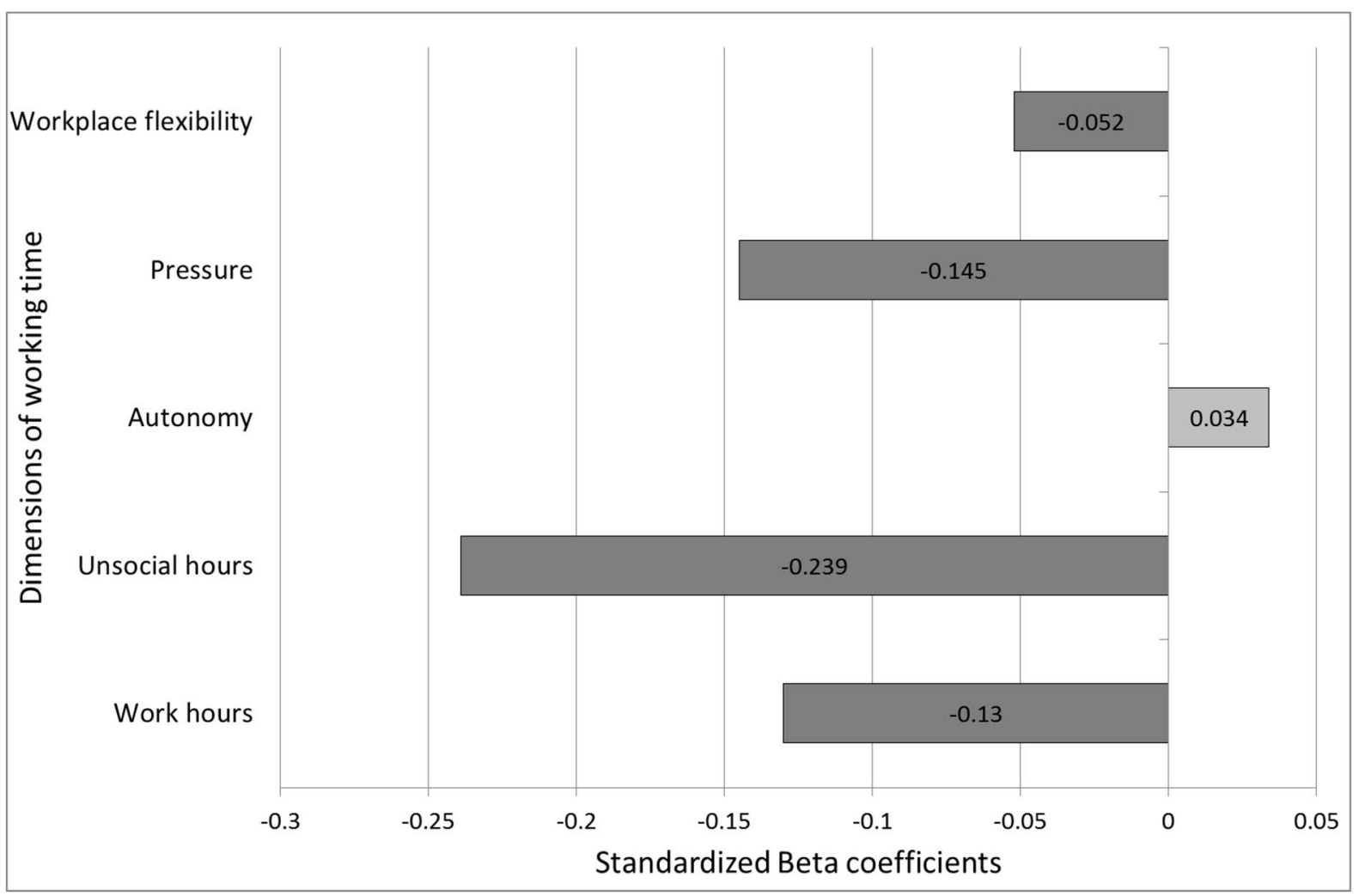

Figure 3. The effects of the dimensions of working time on good work-life balance ${ }^{3}$

\footnotetext{
${ }^{3}$ Working hours fit with family or social commitments outside work well or very well
} 


\section{Conclusions}

Working time aspects are important determinants for the reconciliation of paid work and private life spheres. A good balance between work and life is important for workers. It also has societal value when it supports gender equality.

A good work-life balance has also been proven to be an economic issue that has gained increasing importance in political agendas. When comparing the variation in women's labour-market participation in different European countries and the variation in the perceived work-life balance, a clear correlation can be found. In countries with a good work-life balance, labour-market participation is usually at a high level. By contrast, a poor balance hampers labour supply, while unfit working time arrangements especially discourage women from taking part in working life.

Our empirical evidence indicated that individual autonomy in working times especially enhances a good work-life balance. To make an individual's everyday life flowing and, at the same time, to have boost in labour markets and economy, it is of central importance to focus on working time arrangements that helps people to integrate their paid work and other life commitments. 


\section{REFERENCES}

Adam, B. (1995). Timewatch: The Social Analysis of Time. Oxford: Polity Press.

Anxo, D.and O'Reilly, J. (2000). Working time regimes and transitions in comparative perspective. In J. O'Reilly, I. Cebrian, and M. Lallement (Eds.), Working Time Changes: Social Integration Through Transitional Labour Markets.(pp. 61-90). Cheltenham UK and Northampton, US: Edward Elgar.

Anttila, T., Oinas, T., Tammelin, M., \& Nätti, J. (2015). Working-time regimes and work-life balance in Europe. European Sociological Review, 31(6), 713-724.

Beck, Ulrich: The Brave New World of Work. Polity Press, Cambridge 2000.

Bianchi S. and Milkie, M. (2010). Work and family research in the first decade of the 21st century, Journal of Marriage and the Family,72, 705-725.

Beckers DG, Kompier MA, Kecklund G, Härma M. Worktime control: theoretical conceptualization, current empirical knowledge, and research agenda. Scand J Work Environ Health 2012;38: 291-297.

Bosch, G. (1999). Working time: Tendencies and emerging issues. International Labour Review, 138(2), 131-149.

Bosch, G., Rubery, J., and Lehndorff, S. (2007). European employment models under pressure to change, International Labour Review, 146, 253-277. 
Brannen, J. (2005). Time and the negotiation of work-family boundaries: autonomy or illusion?, Time and Society, 14, 113-131.

Burchell, B., Cartron, D., Csizmadia, P., Delcampe, S., Gollac, M., Illésy, M., Lorenz, E., Makó, C. O'Brien, C. and Valeyre, A. (2009). Working Conditions in the European Union: Working time and Work Intensity (European Foundation for the Improvement of Living and Working Conditions). Luxembourg: Office for Official Publications of the European Communities.

Chatzitheochari, S.and Arber, S. (2012). Class, gender and time poverty: a time use analysis of British workers' free time resources, The British Journal of Sociology, 63, 451-471.

Chung, H.and Tijdens, K. (2013). Working time flexibility components and working time regimes in Europe: using company-level data across 21 countries, The International Journal of Human Resource Management, 24, 1418-1434.

Craig, L.and Powell, A. (2011). Non-standard work schedules, work-family balance and the gendered division of childcare, Work, Employment \& Society, 25, 274-291.

Gray, Matthew, Qu, Lixia, Stanton, David \& Weston, Ruth (2004): Long Work Hours and the Wellbeing of Fathers and their Families. Australian Journal of Labour Economics 7(2):255273. 
Crompton, R. and Lyonette, C. (2006). Work-life 'balance' in Europe, Acta Sociologica, 49, 379-393.

Epstein, C. F.and Kalleberg, A. L. (2001). Time and the sociology of work issues and implications, Work and Occupations, 28, 5-16.

Esping-Andersen, G. (1990). Three Worlds of the Welfare Capitalism. Oxford: Polity Press.

Esping-Andersen, G. (1999). Social Foundations of Postindustrial Economies. Oxford:

Oxford University Press.

Eurofound (2017a), Working time patterns for sustainable work, Publications Office of the European Union, Luxembourg.

Eurofound (2017b), Work-life balance and flexible working arrangements in the European Union, Eurofound, Dublin.

Fagan, C. (2001). The temporal reorganization of employment and the household rhythm of work schedules; The implications for gender and class relations, American Behavioral Scientist, 44, 1199-1212.

Fagan, C., \& Lallement, M. (2000). Working time, social integration and transitional labour markets. Working-Time Changes: Social Integration through Transitional Labour Markets, Edward Elgar, Cheltenham, 61-90. 
Fagan, C., Lyonette C., Smith M., and Saldaña-Tejeda, A. (2012). The influences of working time arrangements on work-life integration or 'balance': a review of the international evidence, Conditions of Work and Employment,Series No. 32. ILO.

Fleetwood, S. (2007). Why work-life balance now?, International Journal of Human Resource Management, 18, 387-400.

Florida, Richard: The Rise of the Creative Class. And How It's Transforming Work, Leisure, Community and Everyday Life. Basic Books, New York 2002.

Gallie, D. and Russell, H. (2009).Work-family conflict and working conditions in Western Europe, Social Indicators Research, 93, 445-467.

Garhammer, Manfred Pace of life and enjoyment of life. Journal of Happiness Studies 3, 217-256. (2002).

Gornick, J. C. and Heron, A. (2006). The regulation of working time as work-family reconciliation policy: comparing Europe, Japan, and the United States, Journal of Comparative Policy Analysis, 8, 149-166.

Golden, L. (2015). Irregular work scheduling and its consequences. Washington, DC: Economic Policy Institute.

Green, F. (2004). Why has work effort become more intense?. Industrial Relations: A Journal of Economy and Society, 43(4), 709-741. 
Grzywacz, J. and Marks, N. (2000). Reconceptualizing the work-family interface: an ecological perspective on the correlates of positive and negative spill-over between work and family, Journal of Occupational Health Psychology, 5, 111-126.

Hill, J.E., Grzywacz, J. G., Allen, S., Blanchard, V. L., Matz-Costa, C., Shulkin, S., andPittCatsouphes, M. (2008). Defining and conceptualizing workplace flexibility, Community, Work and Family, 11, 149-163.

Hochschild, A. The time bind. When work becomes home and home becomes work. Metropolitan Books, New York 1997.

Joyce, K., Pabayo, R., Critchley, J.A. and Bambra, C. (2010). Flexible working conditions and their effects on employee health and wellbeing (review), Cochrane Database Systematic Review, 17.

Karlsson, J. C. (2007). For whom is flexibility good and bad? An overview. B. Furåker, K. Håkansson, \& J. Ch. Karlsson (Eds.), Flexibility and stability in workning life, 18-29.

Kodz, Jenny, et al. (2003) Working long hours: a review of the evidence. Employment Relations Research Series No.16. The Institute for Employment Studies, UK.

Liu, Hui, Wang Qui, Keeler Vanessa \& Schneider, Barbara (2011) Non-standard work schedules, work-family conflict and parental well-being. A comparison of married and cohabiting unions. Social Science Research 40, 473-484. 
McGinnity, F. and Calvert, E. (2009). Work-life conflict and social inequality in Western Europe, Social Indicators Research, 93, 489-508.

Moen, P., Kelly, E., and Huang, Q. (2008). Work, family and life-course fit: does control over work time matter?, Journal of Vocational Behaviour, 73, 414-425.

Nijp, H. H., Beckers, D. G., Geurts, S. A., Tucker, P., \& Kompier, M. A. (2012). Systematic review on the association between employee worktime control and work-non-work balance, health and well-being, and job-related outcomes. Scandinavian journal of work, environment \& health, 299-313.

Noon, M., \& Blyton, P. (1997). The Realities of Work. Macmillan Education UK.

Parent-Thirion, A., Fernández Macías, E., Hurley, J., and Vermeylen, G. (2007). Fourth European Working Conditions Survey (European Foundation for the Improvement of Living and Working Conditions). Luxembourg: Office for Official Publications of the European Communities.

Perrons, D., Fagan, C., McDowell, L., Ray, K., and Ward, K. (2005). 'Work, life and time in the new economy', Time \& Society, 14(1), 51-64. 
Presser, H. B., Crouter, A. C., \& Booth, A. (2006). Employment in a 24/7 economy:

Challenges for the family. Gender divisions and working time in the new economy: Changing patterns of work, care, and public policy in Europe and North America, 35-57.

Rosa, Hartmut: Social Acceleration: Ethical and Political Consequences of a Desynchronised High-Speed Society. Constellations 10(1), 3-33. (2003).

Rubery, J., Smith, M., and Fagan, C. (1998). National working-time regimes and equal opportunities, Feminist Economics, 4(1), 71-101.

Rubery, J., Ward, K., Grimshaw, D., and Beynon, H. (2005). Working time, industrial relations and the employment relationship, Time \& Society, 14, 89-111.

Sennet, Richard: The corrosion of character. The personal consequences of work in the new capitalism. W.W. Norton \& Company, New York \& London 1998.

Steptoe, Andrew, Wardle, Jane, Lipsey, Zara, Mills, R, Oliver, Georgina, Jarvis, Martin \& Kirschbaum, Clemens (1998): A longitudinal study of work load and variations in psychological well-being, cortisol, smoking, and alcohol consumption. Annals of Behavioral Medicine 20(2): 84-91.

Strazdins, L., Korda, R. J., Lim, L., Broom, D. H., and D’Souza, R. M. (2004). Around-theclock: parent work schedules and children's well-being in a 24-h economy, Social Science \& Medicine, 59, 1517-1527. 
Supiot, A., \& Meadows, P. (2001). Beyond employment: Changes in work and the future of labour law in Europe. Oxford University Press on Demand.

Voydanoff, P. (2004). The effects of work demands and resources on work-family conflict and facilitation, Journal of Marriage and Family, 66, 398-412.

Wallace, C., Pichler F., and Hayes, B. (2007). First European Quality of Life Survey: Quality of Work and Life Satisfaction. Dublin: European Foundation for the Improvement of Living and Working Conditions.

Warren, T. (2003). Classand gender-based working time? Time poverty and the division of domestic labour. Sociology, 37(4), 733-752.

Warren, T. (2010). Work time: leisure time: on women's temporal and economic well-being in Europe, Community, Work \& Family, 13, 365-392.

Wight, V. R., Raley, S. B., and Bianchi, S. M. (2008). Time for children, one's spouse and oneself among parents who work nonstandard hours, Social Forces, 87, 243-271.

Täht, Kadri (2011) Out of Sync? The Determinants and Consequences of Nonstandard Schedules for Family Cohesion: The Netherlands Within a Comparative Perspective. Faculty of Social Sciences. Amsterdam, The Netherlands: Free University Amsterdam. 